\title{
"My Name is Damian"
}

\author{
Suzana Tratnik
}

My name is Damian est un monodrame. C'est l'histoire de Damian, un garçon de 19 ans qui se retrouve dans un groupe d'aide pour jeunes à problèmes. Il découvre tranquillement ses problèmes à travers un discours étrange et l'effort de se présenter comme un gagnant. Damian est né en tant que fille mais dénigre ce fait en indiquant qu'il a choisi de changer de nom et de vie. Il passe du temps avec des gais et des lesbiennes mais ne considère pas qu'il partage les mêmes problèmes qu'eux. Il tombe amoureux d'une fille lesbienne mais continue à jouer son rôle masculin et à nier toute forme d'homosexualité. Damian explique au groupe pourquoi son amante lesbienne et lui ont été forcés de se séparer, ce qui est arrivé entre lui et son père quand Damian était encore "la fille de son père " et ce qui l'a amené jusqu'ici. La comédienne qui joue le rôle de Damian est assise au centre du cercle que forme le public qui représente, ici, le groupe d'aide. La voix du psychologue est enregistrée. La pièce dure 45 minutes.

DAMIAN: Hi. My name is Damian. My parents said that I'm not playing with a full deck anymore and that I should just join one of those self-help groups so I won't end up with even more problems. And so, twice a week I meet with a group of nuts and losers. But I'm not saying a word. If I have to, I'll sit in at these meetings every day, from morning till night, and keep my mouth shut. But if you keep pissing me off long enough, you'll hear about it. Just like my folks - they constantly got on my case and then they got what was coming to them. I said "So long, folks!" and I went and had my name legally changed to Damian. I gave myself the name that suits me best.

At home, my parents ranted and raved about what kind of a lunatic they had in their house, a moron, who went and changed his name for no reason "only criminals and felons over in America do things like that when they're too afraid to use their real names. But, of course, that's just not natural. Even dogs have their own names that they always answer to."

"This is not my child, I did not give birth to that!" Like she was talking about an object, a dog or whatever and like I wasn't even there. Mom really didn't have to say those things. My old man just said "why don't you get an operation and completely change so you'll really be an idiot Damian. You were such a good kid when you were little!' But the thing that my parents just don't get is that Damian was never little. Damian always had balls. 
RECORDED VOICE: Good afternoon, everybody! How are you doing in the group? Today we are going to talk about the illnesses of our day.

And now we're going to talk about the illnesses of our day? I really don't know why you choose such depressing topics. You probably got them from some old grandmas or something. Damian hasn't got the time or patience for illness, Damian works and drinks healthy or sick. You know how many times I've partied with a temperature and runny nose?

But this one time was really bad. I had to be taken to the emergency ward. My ovaries were infected. I wouldn't wish that kind of pain on anybody! I had to spend an entire week in hospital and I get getting these huge-mother shots, which themselves made me sick. And it was really annoying at first 'cause the nurses kept looking at each other funny, as if, this one's ovaries are infected? But it looks just like a guy... I pretended to be sleeping and kept an ear open to what they were saying. But I got back at the nurse who was saying that stuff. When she came into our room early in the morning, she wanted to lean over me. I quickly got up and yelled: "Boo!" She just screamed, I really surprised her, then we both just started cracking up. Hey, I told you, Damian can make anyone laugh: the young and old, those from the city and those from the country. Slovenians and imports.

At home, if I say anything that makes people laugh, my father always has a fit about what an idiot they have in the house. He hates the fact that I'm more entertaining than he is, that's why he always send me to the nuthouse:

"The Ljubljana nuthouse calling!"

"If that's how it is, then you go ahead. Afterall, it's free," I once said to him, flipped my bowl over so that my soup spilled all over the place and went to my room.

Let me tell you, illnesses are nothing compared to my father. My old man has to be the worst chronic illness you can get. If it weren't for him, I'd be the healthiest person on Earth. That's why I've got thick skin. I always say, the more the fuck with you're head, the bigger your balls get and the less you get sick.

I used to be an athlete, a lot of sports interested me: basketball, ping pong, shot-put and skiing. My gym teacher said that I should choose a sport as soon as possible, but of course, one that's most suitable for women, otherwise I'd have less opportunities. I didn't like that at all. How's a guy supposed to choose a sport most suited to him if he has to think about what sport is suitable for women and what sport won't affect his school work and what sport his parents would approve of? Maybe that's why I totally neglected any extra activities at the end of my schooling. I'd even skip my regular Phys. Ed classes. Why should I have done anything - if I did, then people would butt into my life even more and give me a hard time like I'd just done who knows what. And that's how my carreer ended. I never did become an athlete, or a woman, I mean, you can't combine either with real life. And since that's the way things are, I didn't want to make things any more complicated for myself and so I chose my own path, Damian's path. It was a path full of bad school grades, social workers and psychologists. 
And I had to find myself, stand on my own two feet, 'cause nothing in this world is ever right. If you have enough money, then you can fix things up so that it's right. But Damian's broke, has no education and he knows that damn well. I'm not so dumb that I don't know that I'm dumb. I don't need my parents to keep telling me that I am. They need me, so that they'll have someone to say that to. That's why they were always furious with me and told me that I'm worthless, and I believed them. I proved that I can do my best to live up to their expectations.

If my old man ever talked about how good I was when I was still "his little Vesna," I'd just laugh at him. When I was little, he used to carry me around in his arms to show everyone what a cute daughter he had. Just me though, he never had that much time for my brother, he wasn't as cute and he'd always piss all over the back seat of the car. I always held it in and didn't just piss all over the place.

My carreer as a good kid ended early as well, right when my father was no longer allowed to touch me.

After everything I went through in my childhood, I never felt good again. Nothing can be fixed here, you can't repair the past. I'd love to meet someone who lucked out and changed their miserable past - I'd buy him or her a beer right away.

RECORDED VOICE OF A PSYCHOLOGIST: There's no help possible after the age of 25. What it means to listen to nice advice and to thicken one's skin. Why Damian's balls have become bigger.

Translated by Elizabeta Zargi

SKUC Theatre Production, Stari trg 21, 1000 Ljubljana, Slovenia, premiered in May 2002, director Alen Jelen, actress Neva Jana Flajs.

"My Name is Damian" is a monodrama: actress playing Damian is sitting in the circle of the theatre audience - the self-help group. The voice of a psychologist is recorded. 